\title{
Mechanisms and pathways of growth failure in primordial dwarfism
}

\author{
Anna Klingseisen and Andrew P. Jackson ${ }^{1}$ \\ MRC Human Genetics Unit, Institute of Genetics and Molecular Medicine, Western General Hospital, Edinburgh EH4 2XU, \\ United Kingdom
}

The greatest difference between species is size; however, the developmental mechanisms determining organism growth remain poorly understood. Primordial dwarfism is a group of human single-gene disorders with extreme global growth failure (which includes Seckel syndrome, microcephalic osteodysplastic primordial dwarfism I [MOPD] types I and II, and Meier-Gorlin syndrome). Ten genes have now been identified for microcephalic primordial dwarfism, encoding proteins involved in fundamental cellular processes including genome replication (ORC1 [origin recognition complex 1], ORC4, ORC6, CDT1, and CDC6), DNA damage response (ATR [ataxia-telangiectasia and Rad3-related]), mRNA splicing (U4atac), and centrosome function (CEP152, PCNT, and CPAP). Here, we review the cellular and developmental mechanisms underlying the pathogenesis of these conditions and address whether further study of these genes could provide novel insight into the physiological regulation of organism growth.

\section{Growth is an important developmental problem}

From the smallest (bumble bee bat, $2 \mathrm{~g}$ ) to the largest (blue whale, $150,000 \mathrm{~kg}$ ), there is a 75 -million-fold difference in the extremes of mammalian growth (Oldham et al. 2000). Likewise, there is substantial variation in the relative size of individual organs. Notably, the brain has undergone a specific and dramatic expansion during evolution to humans, with a 1000 -fold increase in cortical surface area occurring between mice and humans (Rakic 1995). However, our knowledge of factors determining organ and organism size remains limited, in contrast to the extensive knowledge of developmental signaling pathways that determine body pattern. We do not know why humans grow to be larger than mice (Conlon and Raff 1999) or how our arms grow to be the same length (Wolpert 2010). Likewise, we do not know what evolutionary changes caused our brains to expand. Growth dysregulation un-

[Keywords: DNA damage response; DNA replication; cell cycle; centrosome; organism growth; primordial dwarfism]

${ }^{1}$ Corresponding author.

E-mail andrew.jackson@hgu.mrc.ac.uk.

Article is online at http://www.genesdev.org/cgi/doi/10.1101/gad.169037. derlies much human disease and is an essential feature of carcinogenesis.

The overall aim of this review is to place the primordial dwarfism genes in the context of current developmental and cellular knowledge of growth and to explore the mechanisms by which gene mutations perturb growth. We therefore start by providing a brief overview of organism growth and key regulatory pathways in order to provide context. However, this is necessarily selective, and for a more substantive overview the reader is directed to the excellent reviews on the biology of growth regulation written over recent years (e.g., Conlon and Raff 1999; Leevers and McNeill 2005; Edgar 2006; Cook and Tyers 2007).

\section{What determines organism size?}

The size of organisms is set the moment embryogenesis begins. With little variation, flies, mice, humans, and whales attain reproducible sizes. Similarly, organs grow to sizes appropriate to the dimensions of the whole organism. Precisely how genetic programs set such growth limits remains to be elucidated.

Overall size is effectively determined by the composite of cell number and cell volume (Conlon and Raff 1999). Variance in either factor can determine organism size (Fig. 1). In Caenorhabditis elegans, organism size can be changed by up to a factor of 10 through variation in cell volume alone (Watanabe et al. 2007). However, in other species, altered cell size has no net effect on body size, as classically demonstrated in the case of the salamander, where tetraploid animals have cells twice as large as diploid animals but remain the same size, having half the number of cells (Fankhauser 1939).

In mammals, size differences appear to be determined by cell number: The 3000-fold difference in body mass between humans and mice (Fig. 1B) is accounted for by an $\sim 3000$-fold change in cell number (Conlon and Raff 1999). Total cell number is the summation of cells accumulated by cellular proliferation less those lost through cell death. Developmental regulation must inevitably act on one of these two processes. Experimentally, this is exemplified by the dramatic effect on embryonic mouse brain size of altered neural progenitor proliferation (Fig. 1C) or by inhibition of apoptosis (Kuida et al. 1998; Roth et al. 2000; Chenn and Walsh 2002). 


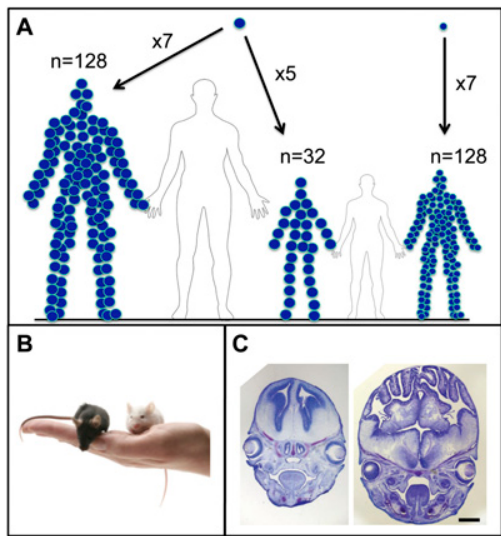

Figure 1. (A) Cell size and cell number determine organism size. Conceptually, body size can be altered through reducing the number of cell divisions or reducing cell size. For example, if during an identical period of development, cells divide only five times out of the usual seven rounds of cell division, this will reduce body volume by $75 \%$. Reducing cell volume to a quarter of normal could similarly reduce body size while maintaining cell number constant. $(B)$ In mammals, body size appears to be predominantly determined by cell number. There is a 3000 -fold difference in body mass between mice $(25 \mathrm{~g})$ and humans $(70 \mathrm{~kg})$, while volume of cells from similar tissues remains relatively unchanged (Conlon and Raff 1999). (C) Cell number can be increased in mammals through alterations in proliferation kinetics. For instance, transgenic expression of stabilized $\beta$-catenin protein enlarges brain size in mice during embryogenesis. Midcoronal sections through the embryonic day 15.5 (E15.5) cerebral cortex from a control mouse embryo (left) and a mouse with the $\Delta 90 \beta$-catenin-GFP transgene expressed in neural precursors, resulting in an enlarged brain with increased cerebral cortical surface area and folds resembling sulci and gyri of higher mammals. Bar, $1 \mathrm{~mm}$. (Image from Chenn and Walsh 2002. Reprinted with permission from AAAS.)

Although on one level mammalian body size can be reduced to the simple problem of controlling cell numbers output during development, the determination of body size is in fact the complex integration of many factors. At the cellular level, cellular proliferation evidently controls cell number, regulated intrinsically by cell cycle regulators and extrinsically by mitogens. Likewise, cell differentiation (resulting in cells exiting from cell cycle) and programmed cell death impact on cell number. Less obviously, cell mass is also an important determinant of cell proliferation, itself regulated by intrinsic factors as well as extrinsically by growth factors and nutrition. Simply to maintain size, cells must double in mass before each cell division. In yeast, it is well established that there is a "restriction point" where cells halt progress in G1 or G2 if they have not grown to a minimum size (Hartwell et al. 1974; Nurse 1975; Jorgensen and Tyers 2004). In metazoans, the situation is less clear, with different experimental systems providing conflicting evidence on the existence of an equivalent "cell size checkpoint" (Echave et al. 2007; Tzur et al. 2009). At the tissue/organ level, further regulation is present, with organs growing to set sizes (the "organ checkpoint") (Leevers and McNeill 2005), and growth regulation of the whole organism is also controlled by the growth hormone/ insulin-like growth factor 1 (GH/IGF1) endocrine axis (Netchine et al. 2011). Additional regulative complexity is provided by opposing signals that stimulate growth and cell survival and those restricting cell size and number (Lui and Baron 2011). Furthermore, regulation of tissue morphogenesis and growth are tightly intertwined, with many morphogens having potent growth-stimulating properties (Leevers and McNeill 2005; Crickmore and Mann 2008).

\section{Cellular pathways regulating growth}

Organism development requires high-fidelity regulatory networks to control and coordinate patterning and growth. Important signaling pathways influencing organ and organism size are summarized in Figure 2. These include insulin growth factor signaling, the Hippo signaling cascade, and the mitogen-activated protein kinase (MAPK) pathways. Also, morphogens such as TGF- $\beta$, Notch, and Wnt are potent regulators of growth alongside their key roles in patterning.

A common theme for these pathways is their integration of multiple inputs and subsequent action on a range of overlapping downstream effectors that modulate growth through cell mass, cell survival, and/or cellular proliferation. The detailed study of growth mutants in model organisms has contributed to the definition of the pathways. Likewise, mutations in some components also cause human genetic syndromes, which exhibit altered growth. In contrast, rather than acting in these signaling pathways, primordial dwarfism genes encode downstream cell proliferation/cell survival proteins. Here, we briefly outline the nature of these pathways, with particular emphasis on downstream effectors to provide a framework for a later examination of how primordial dwarfism genes relate to them (see "Are primordial dwarfism genes regulators of physiological growth?").

\section{IGF signaling/target of rapamycin (TOR) pathway: growth regulation through biosynthesis and cell growth}

Growth hormones play an important part in defining adult body size through systemic hormonal regulation of growth, with mutations in components of the GH/IGF1 axis causing a substantial reduction in human height (Savage et al. 2010). Downstream from the IGF1 receptor, this pathway integrates with other growth signals through the TOR kinase. This kinase integrates IGF1, growth factor, nutrient, and cellular energy signals via an extensive signaling network (Fig. 3A; Caron et al. 2010). Downstream, this master regulator of growth then modulates ribosome biogenesis and translation initiation (Wullschleger et al. 2006). It promotes protein synthesis through the phosphorylation and activation of translational machinery components (Guertin and Sabatini 2007) and inhibits protein degradation (Wullschleger et al. 2006) to promote growth in cell mass.

The insulin/TOR signaling pathway therefore integrates endocrine $(\mathrm{GH} / \mathrm{IGF})$ and paracrine (growth factors) 


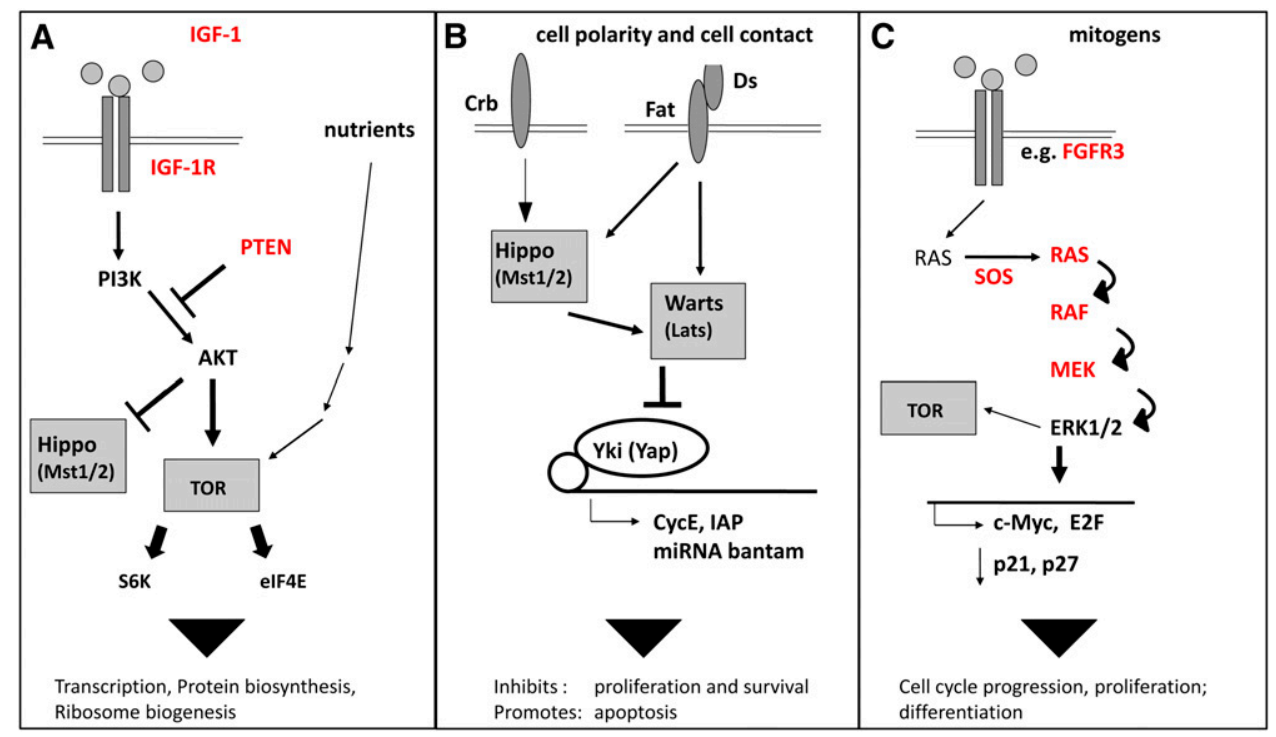

Figure 2. Intracellular signaling pathways regulating growth. PI3K/TOR, Hippo, and MAPK pathways regulate growth by modulating protein translation, cell cycle progression, and apoptosis. Schematic of pathways showing key components. Genes highlighted in red are mutated in human genetic syndromes that manifest growth deficiency or overgrowth. $(A)$ Growth hormone acts systemically through its regulation of IGF-1, which activates phosphotidyl-inosine-3 kinase (PI3K) by binding the IGF-1 receptor (IGF-1R). Subsequent activation of downstream kinases results in increased protein translation and ribosome biosynthesis, leading to cellular growth. The pathway is inhibited by the phosphatase PTEN and integrates multiple other signals, such as nutrient/energy levels, through the master kinase target of rapamycin (TOR). TOR activates the ribosomal S6 kinase and facilitates eIF4E activity to promote translation and transcription initiation. $(B)$ The Hippo pathway restricts growth to control organ size and prevent tissue overgrowth and tumorigenesis. The pathway is currently best defined in Drosophila, where the cell polarity protein Crumbs (Crb) and the protocadherins Fat and Dachsous (Ds) activate Hippo kinase, which in turn activates Warts kinase. The signaling cascade negatively regulates the transcriptional coactivator Yorkie (Yki) by retaining Yki in the cytoplasm. This restricts cell proliferation and promotes cell death, as Yki promotes G1 progression over G0 cell cycle exit through transcriptional up-regulation of Cyclin E (CycE) and the E2F transcription factor. Yki also has an anti-apoptotic effect by inducing inhibitor of apoptosis protein (IAP). The core pathway is conserved in mammals: Mst1/2 (Hippo), Lats (Warts), and Yap (Yki). Homologs to Fat and Ds or the target gene bantam have not yet been identified in mammals. $(C)$ The MAPK (ERK) signaling cascade transduces mitogen signals, driving cellular proliferation by promoting G1-to-S-phase progression (Meloche and Pouysségur 2007). Downstream, ERK kinase activates the proproliferative transcription factors Myc and E2F as well as decreases levels of the cyclin-dependent kinase inhibitors p21 and p27. Rather than being entirely discrete signaling pathways, these three signaling pathways $(A-C)$ overlap; for instance, Akt inhibits Hippo activity, while ERK phosphorylates, and thus activates, TOR.

signals with nutritional status and available energy levels to promote organism growth through increasing cell size (Hietakangas and Cohen 2009). In contrast, the more recently discovered Hippo signaling pathway acts to restrict organ growth, inhibiting cell cycle progression as well as promoting apoptosis (Pan 2010).

\section{The Hippo signaling pathway: controlling organ growth} by regulation of proliferation and cell death

The Hippo serine/threonine kinase is a key component of a growth regulatory pathway conserved from Drosophila to mammals (Dong et al. 2007). In Drosophila, upstream components include atypical cadherins (Bennett and Harvey 2006; Dong et al. 2007) and apical-basal polarity proteins (Grusche et al. 2010), implicating cell adhesion and cell polarity as important inputs to this pathway (Fig. 3B). Downstream, the pathway converges to repress the activity of the transcriptional coactivator Yorkie (Yki) through its phosphorylation and consequent exclusion from the nucleus (Dong et al. 2007). Yki binds multiple transcriptional targets to promote cell proliferation and cell survival. In Drosophila, these include the cell cycle regulators E2F1 (Goulev et al. 2008) and Cyclin E (Tapon et al. 2002), the growth-promoting microRNA bantam (Thompson and Cohen 2006), and the anti-apoptotic protein dIAP (Drosophila inhibitor of apoptosis) (Tapon et al. 2002). Furthermore, the transcription factor dMyc is also a Yki target, which through its own wide range of target genes drives cell proliferation (Neto-Silva et al. 2010; Ziosi et al. 2010).

Overall, the physiological functions for Hippo signaling appear to be in ensuring timely transition from cell proliferation to cellular quiescence and in ensuring proper cellular differentiation (Pan 2010).

Extracellular signal-regulated kinase (Erk) MAPK signaling: mitogen regulation of cell proliferation and cell cycle progression

The ERK1/2 MAPK pathway regulates both growth in cell size and cell cycle progression. It is activated in 
response to virtually all mitogenic factors in diverse cell types (Meloche and Pouyssegur 2007). Mitogen binding to cell surface receptors activates an intracellular cascade of kinases that in turn activate the central serine/ threonine kinases ERK1/2 in this pathway, which then phosphorylate diverse protein substrates (Lewis et al. 1998; Pearson et al. 2001; Yoon and Seger 2006). During the cell cycle, sustained ERK1/2 activity is necessary for the progression from G1 into $S$ phase (Meloche and Pouyssegur 2007). Signaling induces positive regulators of the cell cycle and inhibits the expression of antiproliferative genes. D-type cyclins are induced, promoting G1/S progression. Expression of Cdk inhibitors p21 and p27 is also inhibited, along with maintenance of transcriptional repression of a variety of anti-proliferative genes (Yamamoto et al. 2006; Meloche and Pouyssegur 2007). The ERK1/2 pathway also stimulates global protein synthesis and hence cellular growth through stimulation of rapamycin (mTOR) signaling (Carriere et al. 2008; Mendoza et al. 2011).

\section{Morphogens: controlling growth by regulation of cell proliferation and differentiation}

In Drosophila wing development, increasing or decreasing signaling of the morphogens Wnt (Wingless) or TGF- $\beta$ (Decaplentaplegic) alters wing size to a much greater extent than that resulting from manipulation of the cell cycle or basal growth control. This demonstrates the strength of morphogens as growth-promoting agents (Leevers and McNeill 2005; Crickmore and Mann 2008), which is the consequence of interlinks between growth and pattern generation signaling pathways. For instance, Wnt, TGF- $\beta$, Sonic Hedgehog (Shh), and Notch all impact on Hippo pathway activity (Alarcon et al. 2009; Varelas et al. 2010; Zhao et al. 2010; Heallen et al. 2011). Additionally, morphogens influence cell number through cellular differentiation that frequently results in cell cycle exit. Morphogens may also directly influence cell number through their action on stem cells, regulating their proliferation and differentiation. The TGF- $\beta$ superfamily has a key role in stem cell fate commitment (Kitisin et al. 2007), and Wnt, FGF, Notch, and Hh are also implicated in the maintenance of tissue homeostasis by regulation of stem cell renewal rates, as well as in proliferation or differentiation of progenitors (Katoh 2007).

Despite this extensive knowledge of growth-regulating pathways in animals, how organism size is determined remains substantially unknown. Therefore, the study of relevant human disorders may contribute additional insights. The combination of significant genetic diversity and detailed phenotypic information in humans make us an ideal organism for identification of such physiologically relevant genes (Brenner 2003).

\section{Primordial dwarfism}

Primordial dwarfism is a group of single-gene disorders in which growth is profoundly restricted from very early in development and continues to be impaired postnatally.
Individuals are of "miniature construction with approximately normal anthropometric proportions" (McKusick 1955). In essence, this is a phenotype of extreme global growth failure (Fig. 3A), with final adult height often reduced to as little as $1 \mathrm{~m}$ (Rauch et al. 2008). Neither intensive nutritional nor growth hormone intervention influence growth outcome (Rauch 2011), and this group of disorders perhaps can be best thought of as a "hypocellular" form of dwarfism.

In line with other body parts, most individuals with primordial dwarfism also have a reduction in head size in proportion to, or smaller than, their body size. This microcephaly distinguishes this group from other forms of dwarfism (Fig. 3C). Reduction in head size is the consequence of reduced brain size (cerebral cortical volume) that most likely reflects impaired cellular proliferation during early fetal life, a period known to be critical in determining mammalian brain size (Wood et al. 1967; Friede 1989|. The reduction in brain size is similar to that seen in primary microcephaly, a disorder in which brain growth is specifically impaired (Woods et al. 2005). In both phenotypes, brain size is reduced to approximately a third of normal volume, a size comparable with early humans (Ponting and Jackson 2005). Primordial dwarfism has sometimes been used to describe patients with normal head size (e.g., Russell Silver syndrome); however, such usage is varied and this category is not considered further in this review. Formally, therefore, the conditions that we are discussing in this review are "microcephalic primordial dwarfism."

Microcephalic primordial dwarfism encompasses several distinct disease entities, including Seckel syndrome (Seckel 1960; Majewski and Goecke 1982), microcephalic osteodysplastic primordial dwarfism (MOPD) types I and II (Majewski et al. 1982a,b; Hall et al. 2004), and Meier-Gorlin syndrome (MGS) (Gorlin et al. 1975; Bongers et al. 2001). All are inherited as autosomal recessive traits.

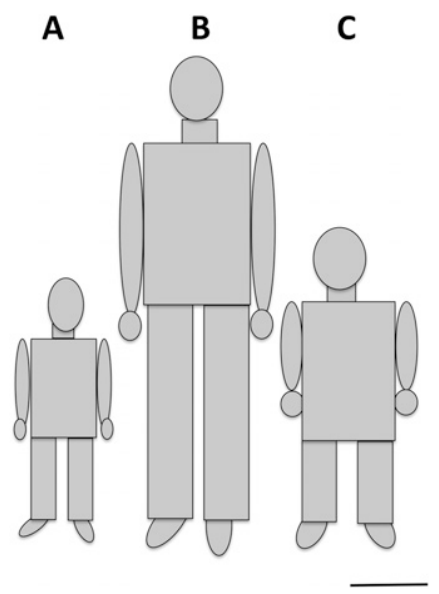

Figure 3. Primordial dwarfism is a disorder of extreme global growth failure. Diagram illustrating the proportionate scaling of body structures in primordial dwarfism $(A)$, relative to those of an adult of average stature $(B) .(C)$ Reduced head size distinguishes primordial dwarfism from other forms of dwarfism (e.g., achondroplasia). Bar, $25 \mathrm{~cm}$. 
Helmut Seckel described a group of patients in his 1960 monograph (Seckel 1960) with "nanocephalic dwarfism" that became known as Seckel syndrome. In this sense, Seckel syndrome is a generic term for microcephalic primordial dwarfism. However, there is substantial variation in usage of this diagnostic term (Al-Dosari et al. 2010; Kalay et al. 2011), and it has also been used specifically to describe a group of patients with more severe learning disability and a head size disproportionately smaller than their bodies (Goodship et al. 2000; Hall et al. 2004; Kalay et al. 2011). Facial features of a receding forehead, prominent nose, and small chin are said to be present (Majewski and Goecke 1982).

In contrast, MOPD II is a well-defined and recognizable form of microcephalic dwarfism (Majewski et al. 1982a; Hall et al. 2004; Rauch 2011). There are characteristic skeletal features as well as distinctive facial features and small loose secondary dentition. Despite severe microcephaly (proportionate to body size), there is well-preserved intellect. However, there is a substantial risk of neurovascular complications (Bober et al. 2010) from both brain aneurysms and arterial narrowings that result in multiple fragile collateral blood vessels (moyamoya). Most individuals also develop significant insulin resistance during childhood, leading to skin pigmentation (acanthosis nigricans) and type II diabetes mellitus (Huang-Doran et al. 2011).

The clinically most severe form of osteodysplastic primordial dwarfism, Taybi-Linder syndrome (also known as MOPD type I or III), has short bowed long bones and profound growth retardation and is lethal within the first 3 yr. It is particularly distinguished by severe brain malformations of the cerebral cortex (pachygyria/aygyria), dry skin, and sparse hair (Sigaudy et al. 1998).

MGS (ear, patella, and short stature syndrome) is a further distinct primordial dwarfism syndrome defined by absent/hypoplastic patellae and markedly small ears (Gorlin et al. 1975; Bongers et al. 2001). Many, but not all, cases have normal intellect with (proportionate) microcephaly, and although some have growth failure as severe as MOPD II, growth failure is variable and can be mild (Bicknell et al. 2011a).

Finally, there are other disorders that can be associated with such substantial growth failure and microcephaly that they overlap with the microcephalic primordial dwarfism group. However, these have additional features that distinguish them, such as distinctive malformations (e.g., Cornelia de Lange syndrome) (Liu and Krantz 2009) or those with immunodeficiency and/or significant cancer predisposition (e.g., Bloom's syndrome) (Hanada and Hickson 2007). They are therefore generally categorized as distinct disease entities. Similarly, there are a substantial number of primordial dwarfism cases that cannot be precisely classified within current diagnostic schemes.

\section{Genes mutated in primordial dwarfism}

To date, 10 genes have been associated with microcephalic primordial dwarfism, seven of which have been published in the last 6 mo (Table 1). Many of these genes have been found to encode proteins that overlap in function, associating the phenotype with specific biological processes.

\section{Defective ataxia-telangiectasia and Rad3-related (ATR)-dependent damage signaling in Seckel syndrome}

The first gene to be identified was ATR, a key phosphotidyl-inosine-3 kinase (PI3K)-like kinase that signals DNA damage (O'Driscoll et al. 2003). ATR is a master regulator of a DNA damage response signaling cascade that responds to RPA-coated ssDNA substrates generated by DNA damage, including those produced at stalled replication forks (for review, see Cimprich and Cortez 2008). It has many similarities to ATM, another PI3K-like kinase that activates a similar, overlapping signaling cascade in response to dsDNA breaks (Shiloh 2001). However, unlike ATM, ATR is an essential gene, due to its role in either regulating orderly cell cycle progression from $S$ phase to mitosis or constitutively stabilizing stalled replication forks that arise physiologically in unperturbed cells (Cimprich and Cortez 2008).

A synonymous homozygous mutation affecting splicing was identified in individuals with Seckel syndrome from two related families (O'Driscoll et al. 2003). This translationally silent mutation led to marked depletion of functional ATR protein through disruption of normal splicing of the gene. Patient cells were found to have a deficient response to ATR-specific damage induction, including defective phosphorlyation of $\mathrm{H} 2 \mathrm{AX}$, a key histone marker of sites of DNA damage and an early event in ATR signal activation. No further mutations have yet been reported in ATR; however, other Seckel syndrome patients have been subsequently found to have defects in ATR signaling (Alderton et al. 2004). Almost all of these cell lines were defective in downstream elements of the ATR signaling pathway, with normal levels of H2AX phosphorylation occurring, suggesting that mutations encoding other components of this cellular pathway could also cause Seckel syndrome.

\section{Centrosomes and primordial dwarfism}

The next gene to be identified was Pericentrin $(P C N T)$, simultaneously reported by two groups (Griffith et al. 2008; Rauch et al. 2008). It encodes a core centrosomal protein that, as a major constituent of the pericentriolar material, facilitates nucleation of the mitotic spindle (Doxsey et al. 1994). Multiple biallelic truncating mutations were identified distributed throughout the gene, which would be expected to completely abrogate protein function. This was surprising, as it had been thought to be an essential protein, given it is required for normal mitosis and primary cilia formation in cell culture (Doxsey et al. 1994; Jurczyk et al. 2004). PCNT patient cells exhibit abnormal mitosis, with impaired mitotic spindle formation and monopolar spindles evident (Rauch et al. 2008), presumably as the consequence of impaired recruitment of $\gamma$-tubulin during centrosome maturation (Griffith et al. 2008). Consequently, 
Table 1. Microcephalic primordial dwarfism genes

\begin{tabular}{|c|c|c|c|c|}
\hline Gene & Condition & $\begin{array}{l}\text { Gene } \\
\text { function }\end{array}$ & $\begin{array}{l}\text { Mutation } \\
\text { type(s) }\end{array}$ & $\begin{array}{l}\text { Distinguishing } \\
\text { features }\end{array}$ \\
\hline ATR & Seckel & $\begin{array}{l}\text { Master kinase of a } \\
\text { DNA damage } \\
\text { response signaling } \\
\text { pathway }\end{array}$ & $\begin{array}{l}\text { Splicing-partial } \\
\text { loss of function }\end{array}$ & $\begin{array}{l}\text { Moderate learning disability, more } \\
\text { marked microcephaly than height } \\
\text { reduction }\end{array}$ \\
\hline PCNT & MOPD II & $\begin{array}{l}\text { Centrosome: major } \\
\text { component of } \\
\text { pericentriolar } \\
\text { material; scaffold for } \\
\text { signaling molecules } \\
\text { (ATR signaling) }\end{array}$ & $\begin{array}{l}\text { Null, truncating } \\
\text { mutations }\end{array}$ & $\begin{array}{l}\text { Skeletal; normal intellect, insulin } \\
\text { resistance; neurovascular } \\
\text { complications; small loose teeth }\end{array}$ \\
\hline CPAP (CENPJ) & Seckel ${ }^{\mathrm{b}}$ & Centriole biogenesis & Splice site mutation & $\begin{array}{l}\text { Proportionate microcephaly and } \\
\text { height reduction; mild learning } \\
\text { disability }\end{array}$ \\
\hline CEP152 & Seckel $^{\mathrm{b}}$ & $\begin{array}{l}\text { Centriole biogenesis, } \\
\text { genome stability }\end{array}$ & $\begin{array}{l}\text { Splice site/missense } \\
\text { mutations; partial } \\
\text { loss of function }\end{array}$ & $\begin{array}{l}\text { Moderate learning disability, more } \\
\text { marked microcephaly }\end{array}$ \\
\hline $\begin{array}{l}\text { ORC1 } \\
\text { ORC4 } \\
\text { ORC6 } \\
\text { CDT1 } \\
\text { CDC6 }\end{array}$ & Meier-Gorlin & $\begin{array}{l}\text { Components of } \\
\text { preRC that licenses } \\
\text { replication origins }\end{array}$ & $\begin{array}{l}\text { Partial loss of } \\
\quad \text { function }\end{array}$ & $\begin{array}{l}\text { Reduced external ear size, } \\
\text { absence/hypoplasia of the patella; } \\
\text { growth more variably affected; } \\
\text { normal intellect }\end{array}$ \\
\hline U4atac & MOPD I & $\begin{array}{l}\text { Component of the } \\
\text { minor spliceosome }\end{array}$ & $\begin{array}{l}\text { Hypomorphic } \\
\text { mutations }\end{array}$ & $\begin{array}{l}\text { Skeletal; brain malformations; } \\
\text { lethal early childhood }\end{array}$ \\
\hline IGF1 & $\begin{array}{l}\text { IGF1 } \\
\text { deficiency }\end{array}$ & $\begin{array}{l}\text { Endocrine/paracrine } \\
\text { growth hormone }\end{array}$ & $\begin{array}{l}\text { Null/partial loss of } \\
\text { function (also one } \\
\text { dominant mutation } \\
\text { described) }\end{array}$ & Sensorineural hearing loss \\
\hline
\end{tabular}

${ }^{a}$ One of the initial reports found mutations in patients with a diagnosis of Seckel syndrome, while the other identified multiple mutations in MOPD II patients. Subsequently, it has been established that patients with PCNT mutations are best described as having MOPD II (Griffith et al. 2008; Rauch et al. 2008; Willems et al. 2009).

${ }^{\mathrm{b}}$ Also associated with mutations in primary microcephaly. CPAP is also known as CENPJ.

cellular proliferation is probably impaired in PCNT patient cells, and a reduction in cell number could then account for the substantial growth failure seen.

However, in addition to its structural role, PCNT is also a scaffold for recruiting proteins such as protein kinase A and CII to the centrosome (Diviani et al. 2000; Chen et al. 2004). Given previous work suggesting ATR signaling defects in Seckel syndrome (Alderton et al. 2004), DNA damage response signaling was assessed in PCNT patients. Surprisingly, PCNT patient cell lines were also defective in ATR-dependent DNA damage response signaling, linking this pathway to the centrosome (Fig. 4A; Griffith et al. 2008). Furthermore, although cells exhibited a defective G2/M checkpoint in response to activation of ATR signaling by UV-C treatment, ATMdependent signaling remained intact, as cells arrested normally in response to ionizing radiation. PCNT has subsequently been shown to act in ATR-dependent damage, signaling G2/M arrest by localizing the effector kinase Chk1 to the centrosome (Tibelius et al. 2009). Centrosomal Chk1 inhibits G2/M transition through inhibition of Cdc25, which in turn inhibits the Cyclin B/Cdk1 kinase (Kramer et al. 2004). However, it is worth noting that a recent study potentially challenges this model, given its reassignment of the centrosomal immunofluorescence signal of the Chk1 monoclonal antibody
(DCS-310) to Ccdc151 (Matsuyama et al. 2011). It also suggests that it is nuclear rather than centrosomal Chk1 that regulates mitotic entry. Hence, precisely how Pericentrin acts in ATR signaling is yet be finalized.

$\mathrm{MCPH1}$, a protein mutated in primary microcephaly, a disorder of reduced brain size, acts as a downstream component of the ATR signaling pathway (Alderton et al. 2006); therefore, mutations in ATR, PCNT, and MCPH1 could all determine size through their regulation of mitotic entry and/or response to DNA damage. This also suggests a functional link between primary microcephaly and microcephalic dwarfism, and there is increasing evidence of overlap between these conditions (Al-Dosari et al. 2010; Guernsey et al. 2010; Kalay et al. 2011). Several other genes encoding centrosomal proteins cause primary microcephaly (Thornton and Woods 2009; Nicholas et al. 2010). Intriguingly, CEP152, encoding a centrosomal gene required for centriolar duplication (Blachon et al. 2008), has been identified as both a primary microcephaly and Seckel syndrome gene in the last year (Guernsey et al. 2010; Kalay et al. 2011). CEP152 also appears to have an unexpected role in maintaining genome integrity and may also interact with ATR through its interaction with CINP, a protein that in turn interacts with the ATRinteracting protein ATRIP (Fig. 4A). Likewise, mutation of CPAP (also known as CENPJ) causes both primary 


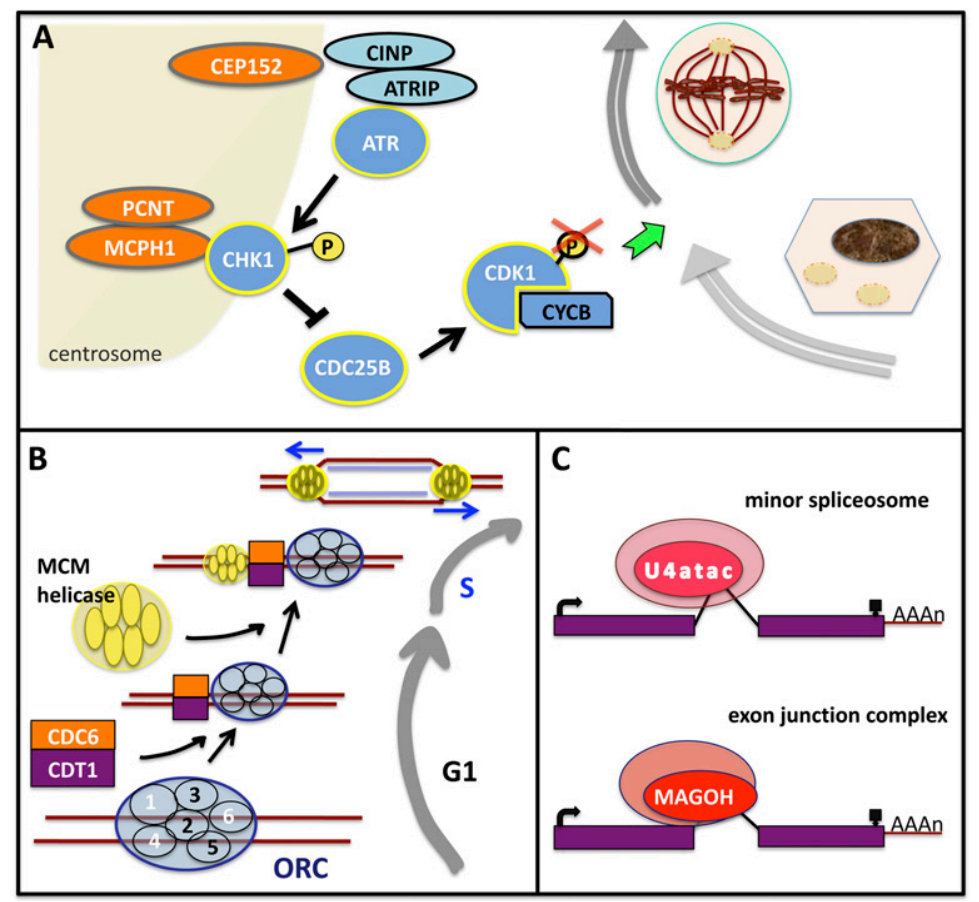

Figure 4. Cellular pathways implicated in primordial dwarfism. (A) ATR DNA damage response signaling. The ATR kinase is activated in response to ssDNA generated by DNA damage. It phosphorylates downstream targets, including the effector kinase Chk1, to coordinate cell cycle arrest, repair the damage, and/or induce apoptosis. Phosphorylation of Chk1 is required for its accumulation at the centrosome (Niida et al. 2007), where it inhibits Cdc25B phosphatase, preventing Cdk1/Cyclin B activation and the transition from G2 to mitosis (Kramer et al. 2004). MCPH1 and PCNT are required for Chk1 localization at the centrosome, and therefore mutations in these genes also impair ATR-induced G2/M checkpoint signaling. Another primordial dwarfism gene, CEP152, interacts with ATR through binding of CINP, which in turn interacts with ATRIP. Genes mutated in primordial dwarfism/primary microcephaly are highlighted in white text. $(B)$ Licensing of replication origins. During G1, the six-subunit ORC assembles at origins of replication. Once the ORC complex is formed, additional factors such as CDC6 and CDT1 are recruited, permitting reiterative loading of the MCM helicase complex (MCM2-7). After G1/ S-phase transition, DNA replication is then initiated by the binding of additional factors and the MCM helicase unwinding DNA at replication forks. $(C)$ mRNA splicing. Splicing of a subpopulation of mRNAs that contain U12-type introns is dependent on the minor spliceosome. The small nuclear ncRNA U4atac is one component of this alternative spliceosome, and mutations in U4atac impair splicing of such introns to a variable degree. U12-dependent introns are found in many genes, including those involved in DNA replication and growth, such as ORC3, MAPKs 1-4, PTEN, and PI3K adaptor protein 1. The exon junction complex (EJC) protein Magoh has also recently been found to be required for splicing of specific genes, including mapk in Drosophila and Lis1 in mice, where it causes microcephaly and growth retardation.

microcephaly and Seckel syndrome (Bond et al. 2005; Al-Dosari et al. 2010). CPAP is the mammalian ortholog of Sas4 (Carvalho-Santos et al. 2010), which is another key element in centriole biogenesis; however, no role in DNA damage response has been described as yet for this protein.

\section{The prereplicative complex (preRC) and MGS}

Recently, a functionally distinct group of genes has been identified. Mutations have been found in ORC1 (origin recognition complex 1), ORC4, ORC6, CDT1, and CDC6 in patients with MGS (Bicknell et al. 2011a,b; Guernsey et al. 2011). All five genes are components of the preRC (Fig. 4B), which assembles on genomic DNA at origins of replication (Mendez and Stillman 2003). The complex is formed by the loading of the ORC (comprising ORC1-6 proteins) onto chromatin during $\mathrm{M}$ and early G1 phases of the cell cycle. Further proteins, including CDC6 and CDT1, are recruited, and the complex then loads the multimeric MCM helicase to complete licensing of the origin. The partial loss-of-function mutations in MGS patients probably impairs this process, leading to reduced MCM helicase loading and consequently less replication origins being licensed.

ORC1 patient cells have reduced levels of chromatinbound MCM protein and their ability to license origins is impaired; however, they proliferate well in cell culture (Bicknell et al. 2011b). This may be explained by the substantial excess of origins that are licensed, leading to many remaining dormant origins during unperturbed genome replication (Woodward et al. 2006). Subtle defects in cell cycle progression were still evident in the patient cells, with delayed G1/S transition and S-phase progression. The former is probably the consequence of activation of a "licensing checkpoint" that acts in primary cells to delay S-phase entry until a critical level of licensed origins has been reached (Ge and Blow 2009; Nevis et al. 2009), while the latter may be the consequence of reduced origin utilization. Notably, in Orc1-depleted zebrafish embryos (Bicknell et al. 2011b) or Saccharomyces cerevisiae cells carrying the Orc4 Y232C mutation (Guernsey et al. 2011), growth was substantially reduced. Cell division is much more rapid in both of these situations than for mammalian cells in culture, suggesting that preRC function might become limiting during very rapid cell cycles. In mammalian development, rapid cellular proliferation (for instance, neural progenitors during early neurogenesis) is associated with substantial shortening of G1 (Takahashi et al. 1995). This would reduce the time available for origin licensing, and hence impaired preRC function could then become rate-limiting, slowing cellular proliferation. This would consequently reduce total cell number and, as a result, organism size.

An alternative is that mutations act in a process independent of replication licensing, since individual ORC genes are also involved in diverse cellular processes, including heterochromatin formation, gene silencing, 


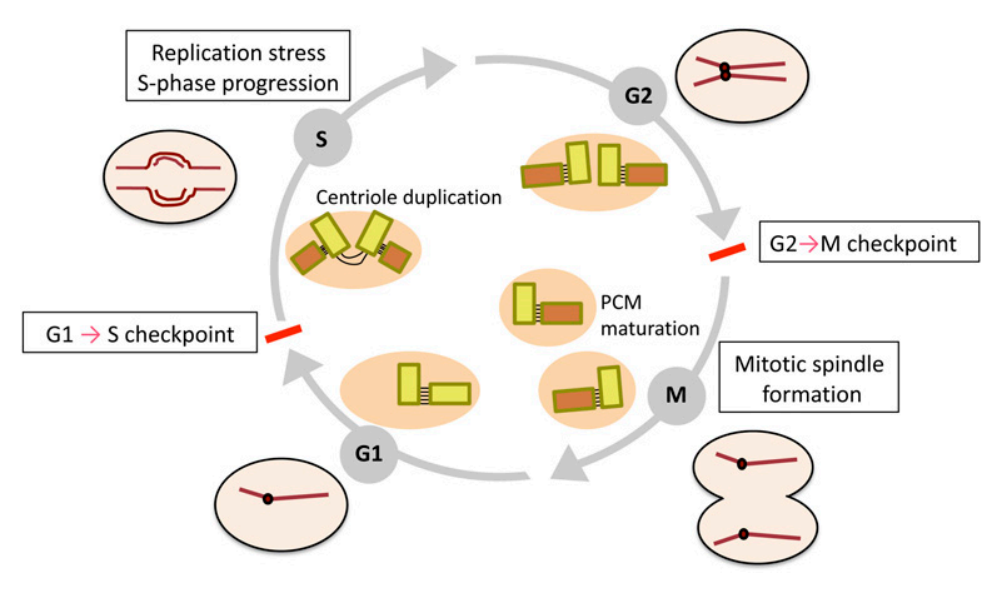

Figure 5. Primordial dwarfism genes act in processes regulating cell cycle progression. Schematic of nuclear and centrosome cycles. Centrosome and genomic DNA duplication are coordinately regulated, with both occurring only once per cell cycle. Mutations in preRC complex proteins impair G1/S transition and S-phase progression. They may also increase replication stress through fewer licensed origins being present. ATR also regulates S-phase progression, as ATR-Seckel mice have increased replication stress during embryogenesis. ATR is then required during G2/M transition, signaling via Chk1 at the centrosome, with localization of Chk1 dependent on MCPH1 and PCNT. PCNT and CEP152 are required for nucleation of the mitotic spindle. Additionally, CEP152 and CPAP (CENPJ), as components of the centriole biogenesis machinery, are essential for centriole duplication, which may also impact on mitotic centrosome integrity later in the cell cycle. and mitosis (Sasaki and Gilbert 2007). Such noncanonical functions could also explain the specific developmental abnormalities seen in MGS patients (absent patella, marked reduction in ear size, and additional malformations, including lower limb deformities, congenital lobar emphysema, and neuronal migration defects). Furthermore, such an association between chromatin-bound complexes involved in essential cellular functions and development is not unprecedented. Notably, in Cornelia de Lange syndrome, mutations in the cohesin complex also cause severe growth retardation, although with very different developmental consequences (Liu and Krantz 2009). However, the identification of mutations in so many ORC subunits, along with the involvement of CDT1 and CDC6, strongly suggests that licensing lies at the heart of pathogenesis in MGS.

\section{Splicing machinery and MOPD I}

Mutation of a minor spliceosome component, the U4atac snRNA, has been recently identified for MOPD I (Edery et al. 2011; He et al. 2011). This lethal condition exhibits profound growth retardation as well as skeletal and brain malformations. The mutations identified generally target a functionally important hairpin loop of this RNA, impairing its role in splicing a small subset of introns, named "U12 introns" (Fig. 4C; Tarn and Steitz 1996). Such introns are only present in $\sim 700$ human genes (Sheth et al. 2006) that encode proteins with a diverse range of functions, including those involved in DNA replication and repair, transcription, RNA processing, and translation (Will and Luhrmann 2005). Expression of some U12-type intron-containing genes appears to be more markedly impaired than others by U4atac snRNA mutations in both humans and Drosophila (Pessa et al. 2010; Edery et al. 2011; He et al. 2011), and it is suggested that perturbation of specific gene transcripts could explain the phenotype.

\section{IGF1 deficiency phenocopies primordial dwarfism}

Growth hormone deficiency and other GH axis defects cause a very marked reduction in final adult height.
However, growth failure is generally postnatal and brain size is spared. In contrast, loss of IGF1 function specifically causes a phenotype that is indistinguishable from primordial dwarfism, with microcephaly and growth failure similar to that seen in MOPD II (Netchine et al. 2011). In contrast to IGF1, GH is not active prenatally, most likely explaining the difference in phenotypes. Notably, most patients with mutations in IGF1 have sensorineural hearing loss and learning difficulties, perhaps suggesting a specific neurodevelopmental requirement for IGF1.

\section{Overlapping mechanisms of growth failure in primordial dwarfism?}

The identified primordial dwarfism genes appear to be involved in overlapping processes regulating cellular proliferation. They do not fall neatly into one cellular process, yet there are interesting functional overlaps (Fig. 5).

A cellular pathway in which ATR signaling intersects with centrosomal proteins appears to be one major emerging theme in microcephalic primordial dwarfism. So, how may mutations act on these processes to cause dwarfism? First, impaired DNA damage response signaling could alter the cellular threshold for cell death resulting from DNA damage, increasing levels of apoptosis during development. Programmed cell death has a substantial effect in determining organ size during development (Kuida et al. 1998; Roth et al. 2000). Growth failure and microcephaly in humans/mice with Ligase IV (LIG4) mutations (Nijnik et al. 2007; Chistiakov et al. 2009) may be the consequence of DNA damage response activation, resulting in substantial apoptosis during development (Frank et al. 2000; Lee et al. 2000). However, in Ligase IV mice, an increase in damage repair also decreases the proliferative potential of progenitors, leading to exhaustion of stem cell pools (Nijnik et al. 2007). Second, mutations may alter the dynamics of mitosis. This is most evident for the centrosomal proteins such as PCNT and CEP152, where mutations lead to impaired mitotic spindle formation (Rauch et al. 2008; Kalay et al. 2011), which could delay mitotic progression and increase the 
proportion of nonviable cell divisions. Third, stem cells may be specifically affected by perturbed centrosomal function. Stem cells undergo asymmetric cell division to generate committed progeny while maintaining their "stem cell identity," with centrosomes playing an important role in such divisions (Knoblich 2010). Notably, ATR and Chk1 have also been found to play a role in asymmetric cell division in the C. elegans embryo, where they act to delay subsequent cell cycle progression specifically in one daughter cell relative to the other (Brauchle et al. 2003). This delay may well have consequences for subsequent developmental fate determination (Budirahardja and Gonczy 2009). Last, the analysis of an ATR mouse model that recapitulates the Seckel syndrome suggests that increased replication stress may be responsible for the phenotype (Murga et al. 2009). Increased replication stress was observed specifically during embryogenesis, associated with raised levels of apoptosis.

ATR has a physiological role in minimizing the deleterious consequences of replication stress resulting from stalled replication forks by reshaping replication origin utilization, directing replication toward active factories where replication forks are inhibited, while inhibiting origin initiation elsewhere (Ge and Blow 2010). Replication stress may therefore also be relevant to etiology of MGS; notably, cellular depletion of the MCM helicase complex leads to increased sensitivity to replication stress (Ge et al. 2007). Mutations in MCM subunits can also impair growth in mice (Chuang et al. 2010). However, such mice also have increased genome instability and cancer predisposition (Shima et al. 2007; Chuang et al. 2010), a feature not evident in MGS patients, suggesting that mutations in MGS genes could be functionally distinct.

Overall, the most plausible unifying hypothesis is that by reducing the efficiency of cell cycle progression, primordial dwarfism genes act to reduce the total cell number generated during development, leading to reduced tissue and organism size. U4atac snRNA mutations do not immediately fit into such a model. However, the effect on transcript splicing is selective (Pessa et al. 2010; Edery et al. 2011; He et al. 2011), and it is quite possible that specific impairment of one of the U12-type intron-containing genes involved in cell cycle control (Sheth et al. 2006) causes the growth failure. Intriguingly, Orc3 is one such gene (Alioto 2007).

ENU-induced mutation in a component of another mRNA transcript-binding complex also influences splicing, causing microcephaly and growth retardation in mice (Silver et al. 2010). MAGOH is a component of the exon junction complex that binds upstream of spliced exons, and, consequently, selective loss of Lis1 (a neuronal proliferation/migration gene) transcripts was seen in mice. Likewise, in Drosophila, mutation of magoh resulted in reduced MAPK transcript levels (Roignant and Treisman 2010; Silver et al. 2010).

\section{Are primordial dwarfism genes regulators of physiological growth?}

Growth is a highly complex process with multiple levels of developmental regulation, exemplified by the 180 height loci identified by human genome-wide association studies (GWAS) studies (Lango Allen et al. 2010). With such complexity, growth failure may therefore often result from secondary consequences rather than primary effects on growth regulatory pathways. Although primordial dwarfism genes are clearly able to alter body size, it thus does not necessarily follow that they are used as physiological regulators of growth. Growth failure could simply be the result of reduced cellular proliferation. However, there are some lines of evidence that could suggest physiological roles for some primordial dwarfism genes. First, the phenotype is consistent with a direct effect on growth, with generally proportionate scaling in the body's structures without other substantial developmental or health problems. Second, phenotype-driven developmental screens for growth have been very successful in identifying important signaling pathways in model organisms (Stocker and Hafen 2000), and there is no reason why human phenotypes should be less informative. Indeed, a significant number of single-gene human disorders that manifest growth failure or overgrowth have mutations in MAPK signaling pathways or IGF1/TOR signaling pathways (genes in red in Fig. 3). Third, the role of primordial dwarfism genes in cellular proliferation provides functional plausibility, particularly given that this is an ultimate target of growth signaling pathways. Last, several of these genes are regulated by known effector proteins of these growth pathways. For instance, E2F transcription factors (downstream from IGF1 and Hippo signaling) regulate ORC1, CDC6 and MCM gene transcription (Ohtani et al. 1996, 1998, 1999; Asano and Wharton 1999), while Myc has been reported to have a nontranscriptional regulative role, directly binding the preRC complex and modulating origin activity (Dominguez-Sola et al. 2007).

Regulating body size through cell proliferation is a conceptually simple mechanism for scaling organism size proportionately. It is striking that most genes identified to date have not been identified as components of core intracellular growth signal transduction pathways. Perhaps this is the result of such signal transduction proteins integrating multiple signals, as well as the interdependent relationships between morphogenetic and growth signaling networks. Thus, disrupting such genes may lead, respectively, to disproportionate local effects on growth or deleterious developmental consequences. For instance, disruption of the Hippo pathway will most likely result in regional rather than global size changes, as conditional ablation of the murine Mst (Hippo) gene using the tamoxifen-inducible CAGGCre-ER line has dramatic effects on the growth of the liver and stomach, but not on the kidney or limb (Song et al. 2010). Likewise, human mutations in MAPK pathway components results in specific developmental defects (e.g., neurocognitive, pigmentary, and cardiac) as the consequence of the pathway's role in diverse cellular processes (Denayer et al. 2008).

Uniquely among developmental signaling pathway genes, mutations in IGF-1 mutations result in the primordial dwarfism phenotype, confirming that at least for this gene, the phenotype is associated with physiological 
growth regulation. In other organisms, IGF1 is also an important determinant of body size. For instance, a regulatory polymorphism of $I G F-1$ is the major determinant of body size in dogs (Sutter et al. 2007), determining the difference between Chihuahuas and Great Danes. Similar phenotypes could suggest a functional link between IGF-1 and other microcephalic primordial dwarfism genes. However, a shared function is not immediately evident, given that IGF1 acts on cell mass to determine growth while the other genes are involved in cell proliferation. This may most easily be clarified by determining the consequence for cell size and number of such primordial dwarfism mutations.

Height in humans is a highly heritable trait for which $90 \%$ of genetic variability still remains unaccounted (Lango Allen et al. 2010). This is despite human GWAS of sequence variants influencing height in studies totaling 184,000 individuals. Mutations in primordial dwarfism genes dramatically affect body size, often proportionately scaling body structures, although, surprisingly, these genes have not been detected in GWAS studies. However, moderate effect variants in the coding or regulatory regions of these genes could well be an important source of physiological regulation of height/body size, accounting for some of the "dark matter" of unidentified genetic variability.

In summary, it is not yet clear whether the primordial dwarfism genes will generally have a role in physiological growth regulation. It could well be that mutations in these genes simply impair cell division, resulting in decreased organism size, and have no physiological role. We may therefore need to await the identification of further primordial dwarfism genes, as well as investigate other human phenotypes, to find novel physiological regulators. In particular, study of human overgrowth syndromes may be informative, analogous to the utility that longevity mutants have had in aging research (Honjoh and Nishida 2011). Such overgrowth syndromes already implicate IGF1/TOR signaling, cell cycle regulators, and chromatin-binding proteins in human growth determination (Rahman 2005; Kant et al. 2007; Verge and Mowat 2010).

\section{Conclusions}

As a whole, the primordial dwarfism genes are involved in cell cycle progression, with organism size most likely reduced in these conditions through reduced cell number. Pathways and functional relationships exist between many of these genes, but they do not fall neatly into one cellular pathway. However, identification of these genes has already provided substantial new insights, such as linking core centrosomal proteins with DNA damage response (Griffith et al. 2008) as well as demonstrating that defects in fundamental replication proteins lead to reduced growth and specific developmental anomalies (Bicknell et al. 2011a,b; Guernsey et al. 2011).

Several interesting questions are raised by the identification of primordial dwarfism genes. First, do these genes act through a general slowing of proliferation in all cells or by specific targeting of rapidly proliferating cells or stem cell division? It is intriguing that the organism does not simply grow for longer to catch up, given established mechanisms that compensate cell size with cell number to maintain a fixed organism mass /Conlon and Raff 1999). Second, do they help to explain evolutionary differences in size between species and within species? Third, in metazoans, growth regulation of cell proliferation appears to be mostly targeted at G1/S progression, but given the known functions of primordial dwarfism genes, is centrosome function and/or the G2/M checkpoint involved in growth regulation? Finally, how could direct effects on cell cycle progression result in proportionate scaling of organism size? Transplantation experiments suggest that organs "know" their size, but how this is set in the context of overall organism size is not established. Organ size could be predetermined at an early stage by progenitor cell number, and this appears to be the case for some organs, but not others (Stanger et al. 2007). Alternatively, systemic (endocrine) signals might respond to adjust organ size in response to the altered cell number and total body mass.

We are at an early stage in understanding the role of primordial dwarfism genes in growth, and further developmental and cellular studies will no doubt provide useful insights. Additionally, many genes remain to be identified for microcephalic primordial dwarfism and could well provide additional surprises. It is hoped that further study of these disorders will advance understanding of the basic mechanisms regulating growth, relevant to human health, and understanding of the evolution of body size. The linkage of such fundamental genes to disease also prompts re-evaluation of assumed functions of these genes both at the cellular level and developmentally.

\section{Acknowledgments}

We thank colleagues in the Jackson laboratory and MRC Human Genetics Unit for helpful discussions and comments, and Martin Raff for his encouragement and comments on the manuscript. We also are grateful to our collaborators for insightful discussions and expert advice. The laboratory is supported by funding from the Medical Research Council and Lister Institute of Preventative Medicine, and A.P.J. is supported by an MRC Senior Clinical Fellowship.

\section{References}

Alarcon C, Zaromytidou AI, Xi Q, Gao S, Yu J, Fujisawa S, Barlas A, Miller AN, Manova-Todorova K, Macias MJ, et al. 2009. Nuclear CDKs drive Smad transcriptional activation and turnover in BMP and TGF- $\beta$ pathways. Cell 139: 757-769.

Alderton GK, Joenje $\mathrm{H}$, Varon $\mathrm{R}$, Borglum $\mathrm{AD}$, Jeggo PA, O'Driscoll M. 2004. Seckel syndrome exhibits cellular features demonstrating defects in the ATR-signalling pathway. Hum Mol Genet 13: 3127-3138.

Alderton GK, Galbiati L, Griffith E, Surinya KH, Neitzel H, Jackson AP, Jeggo PA, O'Driscoll M. 2006. Regulation of mitotic entry by microcephalin and its overlap with ATR signalling. Nat Cell Biol 8: 725-733.

Al-Dosari MS, Shaheen R, Colak D, Alkuraya FS. 2010. Novel CENPJ mutation causes Seckel syndrome. I Med Genet 47: 411-414. 
Alioto TS. 2007. U12DB: a database of orthologous U12-type spliceosomal introns. Nucleic Acids Res 35: D110-D115. doi: $10.1093 / \mathrm{nar} / \mathrm{gk} 1796$.

Asano M, Wharton RP. 1999. E2F mediates developmental and cell cycle regulation of ORC1 in Drosophila. EMBO J 18: 2435-2448.

Bennett FC, Harvey KF. 2006. Fat cadherin modulates organ size in Drosophila via the Salvador/Warts/Hippo signaling pathway. Curr Biol 16: 2101-2110.

Bicknell LS, Bongers EM, Leitch A, Brown S, Schoots J, Harley ME, Aftimos S, Al-Aama JY, Bober M, Brown PA, et al. 2011a. Mutations in the pre-replication complex cause Meier-Gorlin syndrome. Nat Genet 43: 356-359.

Bicknell LS, Walker S, Klingseisen A, Stiff T, Leitch A, Kerzendorfer C, Martin CA, Yeyati P, Al Sanna N, Bober M, et al. 2011b. Mutations in ORC1, encoding the largest subunit of the origin recognition complex, cause microcephalic primordial dwarfism resembling Meier-Gorlin syndrome. Nat Genet 43: 350-355.

Blachon S, Gopalakrishnan J, Omori Y, Polyanovsky A, Church A, Nicastro D, Malicki J, Avidor-Reiss T. 2008. Drosophila asterless and vertebrate Cep152 are orthologs essential for centriole duplication. Genetics 180: 2081-2094.

Bober MB, Khan N, Kaplan J, Lewis K, Feinstein JA, Scott CI Jr, Steinberg GK. 2010. Majewski osteodysplastic primordial dwarfism type II (MOPD II): expanding the vascular phenotype. Am I Med Genet A 152A: 960-965.

Bond J, Roberts E, Springell K, Lizarraga SB, Scott S, Higgins J, Hampshire DJ, Morrison EE, Leal GF, Silva EO, et al. 2005. A centrosomal mechanism involving CDK5RAP2 and CENPJ controls brain size. Nat Genet 37: 353-355.

Bongers EM, Opitz JM, Fryer A, Sarda P, Hennekam RC, Hall BD, Superneau DW, Harbison M, Poss A, van Bokhoven H, et al. 2001. Meier-Gorlin syndrome: report of eight additional cases and review. Am J Med Genet 102: 115-124.

Brauchle M, Baumer K, Gonczy P. 2003. Differential activation of the DNA replication checkpoint contributes to asynchrony of cell division in C. elegans embryos. Curr Biol 13: 819-827.

Brenner S. 2003. Nobel lecture. Nature's gift to science. Biosci Rep 23: 225-237.

Budirahardja Y, Gonczy P. 2009. Coupling the cell cycle to development. Development 136: 2861-2872.

Caron E, Ghosh S, Matsuoka Y, Ashton-Beaucage D, Therrien M, Lemieux S, Perreault C, Roux PP, Kitano H. 2010. A comprehensive map of the mTOR signaling network. Mol Syst Biol 6: 453. doi: 10.1038/msb.2010.108.

Carriere A, Cargnello M, Julien LA, Gao H, Bonneil E, Thibault P, Roux PP. 2008. Oncogenic MAPK signaling stimulates mTORC1 activity by promoting RSK-mediated raptor phosphorylation. Curr Biol 18: 1269-1277.

Carvalho-Santos Z, Machado P, Branco P, Tavares-Cadete F, Rodrigues-Martins A, Pereira-Leal JB, Bettencourt-Dias M. 2010. Stepwise evolution of the centriole-assembly pathway. J Cell Sci 123: 1414-1426.

Chen D, Purohit A, Halilovic E, Doxsey SJ, Newton AC. 2004. Centrosomal anchoring of protein kinase $\mathrm{C} \beta \mathrm{II}$ by pericentrin controls microtubule organization, spindle function, and cytokinesis. J Biol Chem 279: 4829-4839.

Chenn A, Walsh CA. 2002. Regulation of cerebral cortical size by control of cell cycle exit in neural precursors. Science 297: 365-369.

Chistiakov DA, Voronova NV, Chistiakov AP. 2009. Ligase IV syndrome. Eur J Med Genet 52: 373-378.

Chuang $\mathrm{CH}$, Wallace MD, Abratte C, Southard T, Schimenti JC. 2010. Incremental genetic perturbations to MCM2-7 expression and subcellular distribution reveal exquisite sensitivity of mice to DNA replication stress. PLoS Genet 6: e1001110. doi: 10.1371/journal.pgen.1001110.

Cimprich KA, Cortez D. 2008. ATR: an essential regulator of genome integrity. Nat Rev Mol Cell Biol 9: 616-627.

Conlon I, Raff M. 1999. Size control in animal development. Cell 96: 235-244.

Cook M, Tyers M. 2007. Size control goes global. Curr Opin Biotechnol 18: 341-350.

Crickmore MA, Mann RS. 2008. The control of size in animals: insights from selector genes. Bioessays 30: 843-853.

Denayer E, de Ravel T, Legius E. 2008. Clinical and molecular aspects of RAS related disorders. I Med Genet 45: 695-703.

Diviani D, Langeberg LK, Doxsey SJ, Scott JD. 2000. Pericentrin anchors protein kinase $\mathrm{A}$ at the centrosome through a newly identified RII-binding domain. Curr Biol 10: 417-420.

Dominguez-Sola D, Ying CY, Grandori C, Ruggiero L, Chen B, Li M, Galloway DA, Gu W, Gautier J, Dalla-Favera R. 2007. Non-transcriptional control of DNA replication by c-Myc. Nature 448: 445-451.

Dong J, Feldmann G, Huang J, Wu S, Zhang N, Comerford SA, Gayyed MF, Anders RA, Maitra A, Pan D. 2007. Elucidation of a universal size-control mechanism in Drosophila and mammals. Cell 130: 1120-1133.

Doxsey SJ, Stein P, Evans L, Calarco PD, Kirschner M. 1994. Pericentrin, a highly conserved centrosome protein involved in microtubule organization. Cell 76: 639-650.

Echave P, Conlon IJ, Lloyd AC. 2007. Cell size regulation in mammalian cells. Cell Cycle 6: 218-224.

Edery P, Marcaillou C, Sahbatou M, Labalme A, Chastang J, Touraine R, Tubacher E, Senni F, Bober MB, Nampoothiri S, et al. 2011. Association of TALS developmental disorder with defect in minor splicing component U4atac snRNA. Science 332: 240-243.

Edgar BA. 2006. How flies get their size: genetics meets physiology. Nat Rev Genet 7: 907-916.

Fankhauser G. 1939. Polyploidy in the salamander, Eurycea bislineata. J Hered 30: 379-388.

Frank KM, Sharpless NE, Gao Y, Sekiguchi JM, Ferguson DO, Zhu C, Manis JP, Horner J, DePinho RA, Alt FW. 2000. DNA ligase IV deficiency in mice leads to defective neurogenesis and embryonic lethality via the p53 pathway. Mol Cell 5: 993-1002.

Friede RL. 1989. Disturbances in bulk growth. In Developmental neuropathology, pp. 296-308. Springer-Verlag, Berlin.

Ge XQ, Blow JJ. 2009. The licensing checkpoint opens up. Cell Cycle 8: 2320-2322.

Ge XQ, Blow JJ. 2010. Chk1 inhibits replication factory activation but allows dormant origin firing in existing factories. J Cell Biol 191: 1285-1297.

Ge XQ, Jackson DA, Blow JJ. 2007. Dormant origins licensed by excess Mcm2-7 are required for human cells to survive replicative stress. Genes Dev 21: 3331-3341.

Goodship J, Gill H, Carter J, Jackson A, Splitt M, Wright M. 2000. Autozygosity mapping of a seckel syndrome locus to chromosome 3q22.1-q24. Am J Hum Genet 67: 498-503.

Gorlin RJ, Cervenka J, Moller K, Horrobin M, Witkop CJ Jr. 1975. Malformation syndromes. A selected miscellany. Birth Defects Orig Artic Ser 11: 39-50.

Goulev Y, Fauny JD, Gonzalez-Marti B, Flagiello D, Silber J, Zider A. 2008. SCALLOPED interacts with YORKIE, the nuclear effector of the hippo tumor-suppressor pathway in Drosophila. Curr Biol 18: 435-441.

Griffith E, Walker S, Martin CA, Vagnarelli P, Stiff T, Vernay B, Al Sanna N, Saggar A, Hamel B, Earnshaw WC, et al. 2008. Mutations in pericentrin cause Seckel syndrome with de- 
fective ATR-dependent DNA damage signaling. Nat Genet 40: 232-236.

Grusche FA, Richardson HE, Harvey KF. 2010. Upstream regulation of the hippo size control pathway. Curr Biol 20: R574-R582. doi: 10.1016/j.cub.2010.05.023.

Guernsey DL, Jiang H, Hussin J, Arnold M, Bouyakdan K, Perry S, Babineau-Sturk T, Beis J, Dumas N, Evans SC, et al. 2010. Mutations in centrosomal protein CEP152 in primary microcephaly families linked to MCPH4. Am I Hum Genet 87: $40-51$.

Guernsey DL, Matsuoka M, Jiang H, Evans S, Macgillivray C, Nightingale M, Perry S, Ferguson M, LeBlanc M, Paquette J, et al. 2011. Mutations in origin recognition complex gene ORC4 cause Meier-Gorlin syndrome. Nat Genet 43: 360364.

Guertin DA, Sabatini DM. 2007. Defining the role of mTOR in cancer. Cancer Cell 12: 9-22.

Hall JG, Flora C, Scott CI Jr, Pauli RM, Tanaka KI. 2004. Majewski osteodysplastic primordial dwarfism type II (MOPD II): natural history and clinical findings. Am J Med Genet A 130A: 55-72.

Hanada K, Hickson ID. 2007. Molecular genetics of RecQ helicase disorders. Cell Mol Life Sci 64: 2306-2322.

Hartwell LH, Culotti J, Pringle JR, Reid BJ. 1974. Genetic control of the cell division cycle in yeast. Science 183: 46-51.

He H, Liyanarachchi S, Akagi K, Nagy R, Li J, Dietrich RC, Li W, Sebastian N, Wen B, Xin B, et al. 2011. Mutations in U4atac snRNA, a component of the minor spliceosome, in the developmental disorder MOPD I. Science 332: 238-240.

Heallen T, Zhang M, Wang J, Bonilla-Claudio M, Klysik E, Johnson RL, Martin JF. 2011. Hippo pathway inhibits Wnt signaling to restrain cardiomyocyte proliferation and heart size. Science 332: 458-461.

Hietakangas V, Cohen SM. 2009. Regulation of tissue growth through nutrient sensing. Annu Rev Genet 43: 389-410.

Honjoh S, Nishida E. 2011. Two sides of lifespan regulating genes: pro-longevity or anti-longevity? J Biochem 149: 381388.

Huang-Doran I, Bicknell LS, Finucane FM, Rocha N, Porter KM, Tung YC, Szekeres F, Krook A, Nolan JJ, O'Driscoll M, et al. 2011. Genetic defects in human pericentrin are associated with severe insulin resistance and diabetes. Diabetes 60: 925-935.

Jorgensen P, Tyers M. 2004. How cells coordinate growth and division. Curr Biol 14: R1014-R1027. doi: 10.1016/ j.cub.2004.11.027.

Jurczyk A, Gromley A, Redick S, San Agustin J, Witman G, Pazour GJ, Peters DJ, Doxsey S. 2004. Pericentrin forms a complex with intraflagellar transport proteins and polycystin- 2 and is required for primary cilia assembly. J Cell Biol 166: 637-643.

Kalay E, Yigit G, Aslan Y, Brown KE, Pohl E, Bicknell LS, Kayserili H, Li Y, Tuysuz B, Nurnberg G, et al. 2011. CEP152 is a genome maintenance protein disrupted in Seckel syndrome. Nat Genet 43: 23-26.

Kant SG, Kriek M, Walenkamp MJ, Hansson KB, van Rhijn A, Clayton-Smith J, Wit JM, Breuning MH. 2007. Tall stature and duplication of the insulin-like growth factor I receptor gene. Eur J Med Genet 50: 1-10.

Katoh M. 2007. Networking of WNT, FGF, Notch, BMP, and Hedgehog signaling pathways during carcinogenesis. Stem Cell Rev 3: 30-38.

Kitisin K, Saha T, Blake T, Golestaneh N, Deng M, Kim C, Tang Y, Shetty K, Mishra B, Mishra L. 2007. Tgf- $\beta$ signaling in development. Sci STKE 2007: cml. doi: 10.1126/ stke. $3992007 \mathrm{~cm} 1$.
Knoblich JA. 2010. Asymmetric cell division: recent developments and their implications for tumour biology. Nat Rev Mol Cell Biol 11: 849-860.

Kramer A, Mailand N, Lukas C, Syljuasen RG, Wilkinson CJ, Nigg EA, Bartek J, Lukas J. 2004. Centrosome-associated Chk1 prevents premature activation of cyclin-B-Cdk1 kinase. Nat Cell Biol 6: 884-891.

Kuida K, Haydar TF, Kuan CY, Gu Y, Taya C, Karasuyama H, Su MS, Rakic P, Flavell RA. 1998. Reduced apoptosis and cytochrome $c$-mediated caspase activation in mice lacking caspase 9. Cell 94: 325-337.

Lango Allen H, Estrada K, Lettre G, Berndt SI, Weedon MN, Rivadeneira F, Willer CJ, Jackson AU, Vedantam S, Raychaudhuri S, et al. 2010. Hundreds of variants clustered in genomic loci and biological pathways affect human height. Nature 467: 832-838.

Lee Y, Barnes DE, Lindahl T, McKinnon PJ. 2000. Defective neurogenesis resulting from DNA ligase IV deficiency requires Atm. Genes Dev 14: 2576-2580.

Leevers SJ, McNeill H. 2005. Controlling the size of organs and organisms. Curr Opin Cell Biol 17: 604-609.

Lewis TS, Shapiro PS, Ahn NG. 1998. Signal transduction through MAP kinase cascades. Adv Cancer Res 74: 49-139.

Liu J, Krantz ID. 2009. Cornelia de Lange syndrome, cohesin, and beyond. Clin Genet 76: 303-314.

Lui JC, Baron J. 2011. Mechanisms limiting body growth in mammals. Endocr Rev 32: 422-440.

Majewski F, Goecke T. 1982. Studies of microcephalic primordial dwarfism I: approach to a delineation of the Seckel syndrome. Am J Med Genet 12: 7-21.

Majewski F, Ranke M, Schinzel A. 1982a. Studies of microcephalic primordial dwarfism II: the osteodysplastic type II of primordial dwarfism. Am J Med Genet 12: 23-35.

Majewski F, Stoeckenius M, Kemperdick H. 1982b. Studies of microcephalic primordial dwarfism III: an intrauterine dwarf with platyspondyly and anomalies of pelvis and clavicles-osteodysplastic primordial dwarfism type III. Am I Med Genet 12: 37-42.

Matsuyama M, Goto H, Kasahara K, Kawakami Y, Nakanishi M, Kiyono T, Goshima N, Inagaki M. 2011. Nuclear Chk1 prevents premature mitotic entry. I Cell Sci 124: 21132119.

McKusick V. 1955. Primordial dwarfism and ectopia lentis. Am I Hum Genet 7: 189-198.

Meloche S, Pouysségur J. 2007. The ERK1/2 mitogen-activated protein kinase pathway as a master regulator of the G1- to S-phase transition. Oncogene 26: 3227-3239.

Mendez J, Stillman B. 2003. Perpetuating the double helix: molecular machines at eukaryotic DNA replication origins. Bioessays 25: 1158-1167.

Mendoza MC, Er EE, Blenis J. 2011. The Ras-ERK and PI3KmTOR pathways: cross-talk and compensation. Trends Biochem Sci 36: 320-328.

Murga M, Bunting S, Montana MF, Soria R, Mulero F, Canamero M, Lee Y, McKinnon PJ, Nussenzweig A, Fernandez-Capetillo O. 2009. A mouse model of ATR-Seckel shows embryonic replicative stress and accelerated aging. Nat Genet 41: 891898.

Netchine I, Azzi S, Le Bouc Y, Savage MO. 2011. IGF1 molecular anomalies demonstrate its critical role in fetal, postnatal growth and brain development. Best Pract Res Clin Endocrinol Metab 25: 181-190.

Neto-Silva RM, de Beco S, Johnston LA. 2010. Evidence for a growth-stabilizing regulatory feedback mechanism between Myc and Yorkie, the Drosophila homolog of Yap. Dev Cell 19: 507-520. 
Nevis KR, Cordeiro-Stone M, Cook JG. 2009. Origin licensing and p53 status regulate Cdk2 activity during G(1). Cell Cycle 8: 1952-1963.

Nicholas AK, Khurshid M, Desir J, Carvalho OP, Cox JJ, Thornton G, Kausar R, Ansar M, Ahmad W, Verloes A, et al. 2010. WDR62 is associated with the spindle pole and is mutated in human microcephaly. Nat Genet 42: 1010-1014.

Niida H, Katsuno Y, Banerjee B, Hande MP, Nakanishi M. 2007. Specific role of Chk1 phosphorylations in cell survival and checkpoint activation. Mol Cell Biol 27: 2572-2581.

Nijnik A, Woodbine L, Marchetti C, Dawson S, Lambe T, Liu C, Rodrigues NP, Crockford TL, Cabuy E, Vindigni A, et al. 2007. DNA repair is limiting for haematopoietic stem cells during ageing. Nature 447: 686-690.

Nurse P. 1975. Genetic control of cell size at cell division in yeast. Nature 256: 547-551.

O'Driscoll M, Ruiz-Perez VL, Woods CG, Jeggo PA, Goodship JA. 2003. A splicing mutation affecting expression of ataxiatelangiectasia and Rad3-related protein (ATR) results in Seckel syndrome. Nat Genet 33: 497-501.

Ohtani K, DeGregori J, Leone G, Herendeen DR, Kelly TJ, Nevins JR. 1996. Expression of the HsOrcl gene, a human ORC1 homolog, is regulated by cell proliferation via the E2F transcription factor. Mol Cell Biol 16: 6977-6984.

Ohtani K, Tsujimoto A, Ikeda M, Nakamura M. 1998. Regulation of cell growth-dependent expression of mammalian CDC6 gene by the cell cycle transcription factor E2F. Oncogene 17: 1777-1785.

Ohtani K, Iwanaga R, Nakamura M, Ikeda M, Yabuta N, Tsuruga H, Nojima H. 1999. Cell growth-regulated expression of mammalian MCM5 and MCM6 genes mediated by the transcription factor E2F. Oncogene 18: 2299-2309.

Oldham S, Bohni R, Stocker H, Brogiolo W, Hafen E. 2000. Genetic control of size in Drosophila. Philos Trans $R$ Soc Lond B Biol Sci 355: 945-952.

Pan D. 2010. The hippo signaling pathway in development and cancer. Dev Cell 19: 491-505.

Pearson G, Robinson F, Beers Gibson T, Xu BE, Karandikar M, Berman K, Cobb MH. 2001. Mitogen-activated protein (MAP) kinase pathways: regulation and physiological functions. Endocr Rev 22: 153-183.

Pessa HK, Greco D, Kvist J, Wahlstrom G, Heino TI, Auvinen P, Frilander MJ. 2010. Gene expression profiling of U12-type spliceosome mutant Drosophila reveals widespread changes in metabolic pathways. PLOS ONE 5: e13215. doi: 10.1371/ journal.pone.0013215.

Ponting C, Jackson AP. 2005. Evolution of primary microcephaly genes and the enlargement of primate brains. Curr Opin Genet Dev 15: 241-248.

Rahman N. 2005. Mechanisms predisposing to childhood overgrowth and cancer. Curr Opin Genet Dev 15: 227-233.

Rakic P. 1995. A small step for the cell, a giant leap for mankind: a hypothesis of neocortical expansion during evolution. Trends Neurosci 18: 383-388.

Rauch A. 2011. The shortest of the short: Pericentrin mutations and beyond. Best Pract Res Clin Endocrinol Metab 25: 125130.

Rauch A, Thiel CT, Schindler D, Wick U, Crow YJ, Ekici AB, van Essen AJ, Goecke TO, Al-Gazali L, Chrzanowska KH, et al. 2008. Mutations in the Pericentrin (PCNT) gene cause primordial dwarfism. Science 319: 816-819.

Roignant JY, Treisman JE. 2010. Exon junction complex subunits are required to splice Drosophila MAP kinase, a large heterochromatic gene. Cell 143: 238-250.

Roth KA, Kuan C, Haydar TF, D'Sa-Eipper C, Shindler KS, Zheng TS, Kuida K, Flavell RA, Rakic P. 2000. Epistatic and independent functions of caspase-3 and Bcl-X(L) in developmental programmed cell death. Proc Natl Acad Sci 97: 466-471.

Sasaki T, Gilbert DM. 2007. The many faces of the origin recognition complex. Curr Opin Cell Biol 19: 337-343.

Savage MO, Burren CP, Rosenfeld RG. 2010. The continuum of growth hormone-IGF-I axis defects causing short stature: diagnostic and therapeutic challenges. Clin Endocrinol (Oxf) 72: 721-728.

Seckel HPG. 1960. Bird-headed dwarfs. S. Karger, Basel.

Sheth N, Roca X, Hastings ML, Roeder T, Krainer AR, Sachidanandam R. 2006. Comprehensive splice-site analysis using comparative genomics. Nucleic Acids Res 34: 3955-3967.

Shiloh Y. 2001. ATM and ATR: networking cellular responses to DNA damage. Curr Opin Genet Dev 11: 71-77.

Shima N, Alcaraz A, Liachko I, Buske TR, Andrews CA, Munroe RJ, Hartford SA, Tye BK, Schimenti JC. 2007. A viable allele of $\mathrm{Mcm} 4$ causes chromosome instability and mammary adenocarcinomas in mice. Nat Genet 39: 93-98.

Sigaudy S, Toutain A, Moncla A, Fredouille C, Bourliere B, Ayme S, Philip N. 1998. Microcephalic osteodysplastic primordial dwarfism Taybi-Linder type: report of four cases and review of the literature. Am I Med Genet 80: 16-24.

Silver DL, Watkins-Chow DE, Schreck KC, Pierfelice TJ, Larson DM, Burnetti AJ, Liaw HJ, Myung K, Walsh CA, Gaiano N, et al. 2010. The exon junction complex component Magoh controls brain size by regulating neural stem cell division. Nat Neurosci 13: 551-558.

Song H, Mak KK, Topol L, Yun K, Hu J, Garrett L, Chen Y, Park O, Chang J, Simpson RM, et al. 2010. Mammalian Mst1 and Mst2 kinases play essential roles in organ size control and tumor suppression. Proc Natl Acad Sci 107: 1431-1436.

Stanger BZ, Tanaka AJ, Melton DA. 2007. Organ size is limited by the number of embryonic progenitor cells in the pancreas but not the liver. Nature 445: 886-891.

Stocker H, Hafen E. 2000. Genetic control of cell size. Curr Opin Genet Dev 10: 529-535.

Sutter NB, Bustamante CD, Chase K, Gray MM, Zhao K, Zhu L, Padhukasahasram B, Karlins E, Davis S, Jones PG, et al. 2007. A single IGF1 allele is a major determinant of small size in dogs. Science 316: 112-115.

Takahashi T, Nowakowski RS, Caviness VS Jr. 1995. The cell cycle of the pseudostratified ventricular epithelium of the embryonic murine cerebral wall. I Neurosci 15: 60466057.

Tapon N, Harvey KF, Bell DW, Wahrer DC, Schiripo TA, Haber DA, Hariharan IK. 2002. salvador promotes both cell cycle exit and apoptosis in Drosophila and is mutated in human cancer cell lines. Cell 110: 467-478.

Tarn WY, Steitz JA. 1996. Highly diverged U4 and U6 small nuclear RNAs required for splicing rare AT-AC introns. Science 273: 1824-1832.

Thompson BJ, Cohen SM. 2006. The Hippo pathway regulates the bantam microRNA to control cell proliferation and apoptosis in Drosophila. Cell 126: 767-774.

Thornton GK, Woods CG. 2009. Primary microcephaly: do all roads lead to Rome? Trends Genet 25: 501-510.

Tibelius A, Marhold J, Zentgraf H, Heilig CE, Neitzel H, Ducommun B, Rauch A, Ho AD, Bartek J, Kramer A. 2009. Microcephalin and pericentrin regulate mitotic entry via centrosome-associated Chk1. J Cell Biol 185: 1149-1157.

Tzur A, Kafri R, LeBleu VS, Lahav G, Kirschner MW. 2009. Cell growth and size homeostasis in proliferating animal cells. Science 325: 167-171.

Varelas X, Miller BW, Sopko R, Song S, Gregorieff A, Fellouse FA, Sakuma R, Pawson T, Hunziker W, McNeill H, et al. 
2010. The Hippo pathway regulates Wnt/ $\beta$-catenin signaling. Dev Cell 18: 579-591.

Verge CF, Mowat D. 2010. Overgrowth. Arch Dis Child 95: 458463.

Watanabe N, Ishihara T, Ohshima Y. 2007. Mutants carrying two sma mutations are super small in the nematode $C$. elegans. Genes Cells 12: 603-609.

Will CL, Luhrmann R. 2005. Splicing of a rare class of introns by the U12-dependent spliceosome. Biol Chem 386: 713-724.

Willems M, Genevieve D, Borck G, Baumann C, Baujat G, Bieth E, Edery P, Farra E, Gerard M, Heron D, et al. 2009. Molecular analysis of Pericentrin gene (PCNT) in a series of 24 Seckel/MOPD II families. I Med Genet 47: 797-802.

Wolpert L. 2010. Arms and the man: the problem of symmetric growth. PLoS Biol 8: e1000477. doi: 10.1371/journal. pbio. 1000477.

Wood JW, Johnson KG, Omori Y. 1967. In utero exposure to the Hiroshima atomic bomb. An evaluation of head size and mental retardation: twenty years later. Pediatrics 39: 385-392.

Woods CG, Bond J, Enard W. 2005. Autosomal recessive primary microcephaly (MCPH): a review of clinical, molecular, and evolutionary findings. Am J Hum Genet 76: 717-728.

Woodward AM, Gohler T, Luciani MG, Oehlmann M, Ge X, Gartner A, Jackson DA, Blow JJ. 2006. Excess Mcm2-7 license dormant origins of replication that can be used under conditions of replicative stress. J Cell Biol 173: 673-683.

Wullschleger S, Loewith R, Hall MN. 2006. TOR signaling in growth and metabolism. Cell 124: 471-484.

Yamamoto T, Ebisuya M, Ashida F, Okamoto K, Yonehara S, Nishida E. 2006. Continuous ERK activation downregulates antiproliferative genes throughout G1 phase to allow cellcycle progression. Curr Biol 16: 1171-1182.

Yoon S, Seger R. 2006. The extracellular signal-regulated kinase: multiple substrates regulate diverse cellular functions. Growth Factors 24: 21-44.

Zhao B, Li L, Guan KL. 2010. Hippo signaling at a glance. J Cell Sci 123: 4001-4006.

Ziosi M, Baena-Lopez LA, Grifoni D, Froldi F, Pession A, Garoia F, Trotta V, Bellosta P, Cavicchi S. 2010. dMyc functions downstream of Yorkie to promote the supercompetitive behavior of hippo pathway mutant cells. PLoS Genet 6: e1001140. doi: 10.1371/journal.pgen.1001140. 


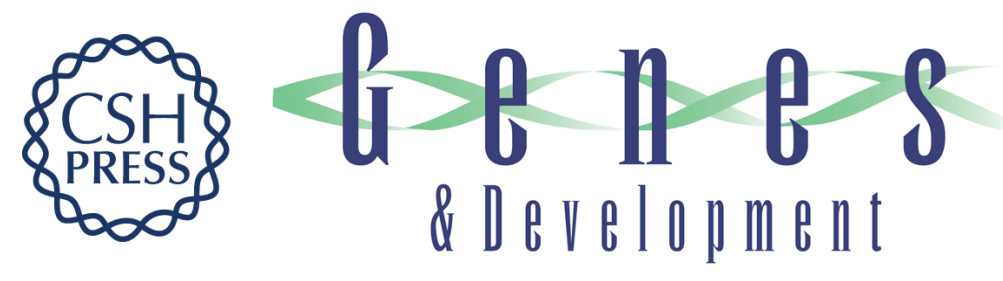

\section{Mechanisms and pathways of growth failure in primordial dwarfism}

Anna Klingseisen and Andrew P. Jackson

Genes Dev. 2011, 25:

Access the most recent version at doi:10.1101/gad.169037

References This article cites 134 articles, 32 of which can be accessed free at: http://genesdev.cshlp.org/content/25/19/2011.full.html\#ref-list-1

License

Email Alerting Receive free email alerts when new articles cite this article - sign up in the box at the top Service right corner of the article or click here.

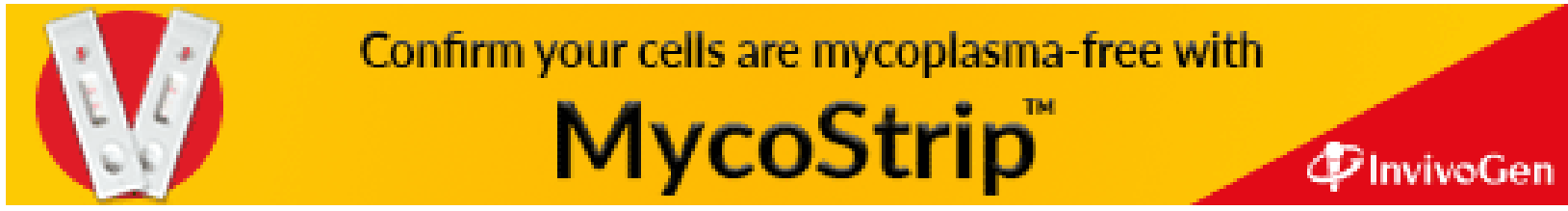

